\title{
Boat disturbance effects on moulting common eiders Somateria mollissima
}

\author{
Nina Dehnhard ${ }^{1}$ (D) Jørgen Skei ${ }^{2}$. Signe Christensen-Dalsgaard ${ }^{1} \cdot$ Roel May $^{1} \cdot$ Duncan Halley $^{1}$. \\ Thor Harald Ringsby ${ }^{2}$. Svein-Håkon Lorentsen ${ }^{1}$
}

Received: 26 August 2019 / Accepted: 14 November 2019 / Published online: 26 December 2019

(C) The Author(s) 2019

\begin{abstract}
Ship and boat traffic are increasing sources of disturbance to marine wildlife. During moult, sea ducks are flightless and rely on productive and shallow feeding areas. However, this period coincides with the peak of the recreational boating season. This is the first study to investigate the escape behaviour of moulting common eiders (Somateria mollissima) to the approach of small boats. We quantified flight initiation distances (flock-to-boat distance at which an energy-demanding escape occurred), displacement distances (distance between the pre- and post-disturbance position of the flock) and the time it took flocks to return to pre-disturbance (foraging- or resting-) behaviour. Moulting common eiders showed average flight initiation distances of $177 \mathrm{~m}$ and displacement distances of $771 \mathrm{~m}$. Displacement distances decreased with flock size, under higher wind speeds and when previous foraging habitat was shallower. Time-to-return to pre-disturbance behaviour decreased with flock size but increased with wind speed and accessibility of foraging habitat at the previous location. Most $(75 \%)$ of flocks returned to pre-disturbance behaviour within $10 \mathrm{~min}$ after the disturbance, while three flocks kept disturbed even $45 \mathrm{~min}$ after the approach. Finally, flocks encountered less accessible (deeper) habitats after disturbance than before. Our results suggest that approaching boats imply considerable disturbance effects for moulting common eiders through increased locomotion costs, displacement from accessible foraging habitat and/or time lost for foraging or resting. We provide valuable information for policy makers and marine spatial planning and highlight the need for awareness among recreational boat drivers on their impact on wildlife.
\end{abstract}

\section{Introduction}

Boat and ship traffic worldwide are on the rise (United Nations Conference on Trade and Development-UNCTAD 2018), particularly in coastal areas (Marine Traffic

Responsible Editor: V. Paiva.

Reviewed by Undisclosed experts.

Electronic supplementary material The online version of this article (https://doi.org/10.1007/s00227-019-3624-z) contains supplementary material, which is available to authorized users.

Nina Dehnhard

nina.dehnhard@nina.no

1 Norwegian Institute for Nature Research (NINA), 7485 Trondheim, Norway

2 Department of Biology, Centre for Biodiversity Dynamics, Norwegian University of Science and Technology (NTNU), 7491 Trondheim, Norway
2013-2019). In addition to commercial ship traffic, the recreational use of yachts, motorboats and personal watercrafts (e.g. jet skis) worldwide has increased strongly in the last decades. This has manifold impacts on the coastal environment (Davenport and Davenport 2006), especially since many recreational users also enter marine reserves (Gonson et al. 2016). The increase in ship and boat traffic is likely to have an impact on wildlife, especially marine mammals (Lusseau 2005), seabirds (Ronconi and St. Clair 2002; Velando and Munilla 2011) and sea ducks (Schwemmer et al. 2011). It has, for example, been shown that species such as loons (Gavia ssp.) and common scoters (Melanitta nigra) tend to avoid areas with high ship traffic (Bellebaum et al. 2006; Kaiser et al. 2006; Schwemmer et al. 2011).

From a theoretical point of view, wildlife might perceive approaching boats and ships in the same way as intruding predators (Frid and Dill 2002) and therefore respond accordingly. By displaying alert behaviour, flocks of birds signal an approaching predator upfront that it has been detected, which may discourage the predator from attacking (Jacobsen and 
Morten 1992; Caro 2005). By doing so, the birds can remain in the vicinity of their previous foraging site. Optimal foraging theory (cf. Stephens and Krebs 1986) also predicts that if the foraging habitat is of high quality, prey species will initiate their escape response later and show a lower displacement distance (i.e. the distance between original location and location after disturbance) than if pre-disturbance foraging habitat is of low quality (Ydenberg and Dill 1986). Finally, independent of foraging habitat, birds may get habituated to regularly used shipping routes. Hence, flocks of common eider (Somateria mollisima) and long-tailed ducks (Clangula hyemalis) showed shorter flight initiation distances (i.e. the distance between ship and birds at which birds start to fly off or dive away) in shipping lanes than outside of shipping lanes in offshore areas of the North and Baltic Sea during winter (Schwemmer et al. 2011). Thus, habituation might save energy, since flight costs in sea ducks are exceptionally high. For instance, Pelletier et al. (2008) showed that $10 \mathrm{~min} /$ day in flight amounts to $4-5 \%$ of their daily energy budget and that flight times are minimized to save energy. However, unlike commercial ship traffic, recreational boats and fishing vessels are unpredictable in speed and course and therefore pose a higher disturbance potential for birds (Schwemmer et al. 2011). Furthermore, recreational activities take place mostly in coastal waters, and thus overlap spatially with the habitat of sea ducks, which increases the potential for disturbance. This was demonstrated in a study from Southwestern Greenland where persistent traffic of small, fast moving, open boats had cumulative disturbance effects on wintering common eiders, with significantly decreased time for feeding (up to a $60 \%$ decrease) while locomotion activity tripled (Merkel et al. 2009).

For sea ducks, the moulting period, initiated after egg laying for males and during and after the chick-rearing period in females is especially energy demanding. In Norwegian waters, common eider males moult during July and August, whereas for females the moulting period is August and September. Moulting sea ducks lose their flight feathers simultaneously which restrict their diving and flight abilities, and increase their energy expenditure, which for the common eider is $9 \%$ higher during moult compared to the post-moult period (Guillemette et al. 2007). Due to their restricted dive capabilities sea ducks therefore moult in shallow areas with high food availability (Fox et al. 2008). A recent study on common eiders indicated carry-over effects of energetic demands and stress (measured as baseline corticosterone in feathers) from the moult period to the subsequent breeding season (Harms et al. 2015). Females with lower feather corticosterone concentrations (and thus less stress during moult) had a higher body mass, arrived earlier in their breeding colonies and showed higher breeding success and survival (Harms et al. 2015). Disturbance effects during moult, especially when these lead to displacement from optimal foraging areas, could therefore have potential carry-over effects on individual fitness and possibly population trajectories. Although the moult period is a particularly sensitive period in the ducks' annual life cycle, very few assessments of the effects of boat traffic on moulting sea ducks have been performed.

By experimentally approaching flocks of moulting common eiders, this study aimed to improve the understanding of the impact of boat traffic during the moulting period. In particular we assessed the birds' behavioural reaction in response to decreasing flock-to-boat distance, distinguishing between undisturbed and alert behaviour, swimming away from the boat, flying (in few cases of eiders that had not initiated moult during the study period), escaping with flapping wings and diving. Furthermore, we assumed that flapping/diving away, particularly in a stressful situation as an escape from a boat (perceived as a potential predator), is similarly energetically costly for common eiders as flying (Pelletier et al. 2008). Thus, flight initiation distances during decreasing flock-to-boat distance at which birds initiated energy-demanding escape responses as diving, escaping with flapping wings or flying were measured. Then, to gain better insights into the potential energetic consequences of boat disturbances, we measured the displacement distances (i.e. the distance the birds moved away from their initial position) and the time it took for a flock to regain pre-disturbance behaviour (i.e. an indication for the time loss associated with the disturbance which would have otherwise been used for feeding, resting or social activities). We further assessed the proportion of accessible benthic foraging habitat (indicated by suitable water depths for foraging in a radius of $150 \mathrm{~m}$ around the position of the flock) before and after the disturbance. We hypothesized that the proportion of accessible foraging habitat would be higher before compared to after the disturbance. Finally, to improve our understanding of the potential consequences of the disturbance on the foraging abilities, we investigated whether displacement distance and time-to-return to pre-disturbance behaviour were linked to accessible foraging habitat, but also variables such as flock size, wind speed, tide, and time of day. These variables were included since they may influence activity patterns of the ducks: Flight initiation distances have been shown to be positively correlated with flock size (Schwemmer et al. 2011) and wind speed (Laursen et al. 2005), and both factors may consequently also influence displacement distances and time-to-return to pre-disturbance behaviour. Eider ducks typically show a peak in foraging activities during morning and evening hours and also during low tide (Minot 1980; Systad and Bustnes 2001; Merkel et al. 2009). Both time of day and tide may thus affect particularly their time-to-return to predisturbance and foraging activities. 


\section{Methods}

\section{Study site}

The study was conducted between the 6th and 24th of August 2013 in shallow coastal areas in central Norway, near the islands Grip ( $\left.63^{\circ} 13.20 \mathrm{~N}, 7^{\circ} 36.16 \mathrm{E}\right)$, Smøla $\left(63^{\circ} 25.00 \mathrm{~N}, 7^{\circ} 48.95 \mathrm{E}\right)$ and Frøya $\left(63^{\circ} 45.47 \mathrm{~N}, 8^{\circ}\right.$ 17.34 E; see Fig. 1). The area is characterized by few large main islands surrounded by many smaller islands, islets and small skerries and shallow waters, which creates particularly suitable foraging habitats for common eiders. This was confirmed by an aerial count of moulting eiders completed in July and August 2012, based on which we identified possible locations for our experimental approach. During summer (June-August) these areas are popular for recreational boating and both recreational and commercial fishing, and thus hold potential for moulting common eiders to be disturbed.

The breeding populations of common eiders have been declining along the Norwegian Atlantic and North Sea coasts (Anker-Nilssen et al. 2015), and similar trends are visible in Sweden and Finland (Kilpi et al. 2015). Systematic count data for the breeding season from the study area are missing, thus not allowing information on a population trend in this specific area. However, the number of common eiders wintering around the island of Smøla has decreased annually by $3.9 \%$ between 1980 and 2013 (estimate based on annual count data, trend estimate calculated following methodology in Žydelis et al. 2006).

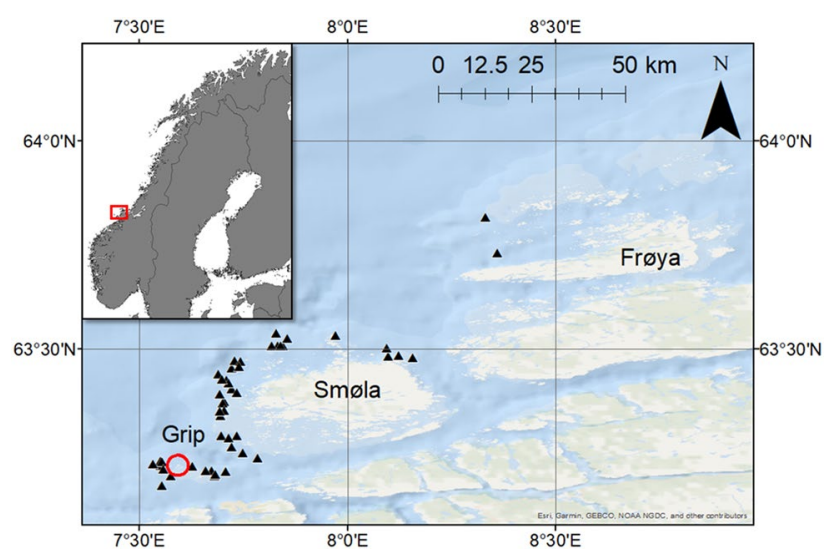

Fig. 1 Overview map of the study area. The inset map shows the location of the study area within Northern Europe (red box). Triangles in the main map indicate the locations of the eider flocks prior to disturbance. The location of the island of Grip is highlighted with a red circle

\section{Experimental design and data collection}

We used two recreational motor boats to approach and experimentally disturb common eider flocks; a Korsö 1100 with a $500 \mathrm{hp}$ engine, and a Skorgenes 350 with a $400 \mathrm{hp}$ engine, both being $11 \mathrm{~m}$ long, and with a height of ca. $3 \mathrm{~m}$ from sea level to the wheelhouse, and $5 \mathrm{~m}$ from sea level to the top of the antennas.

Before approaching a flock, birds were counted and observed from a distance $(250-1500 \mathrm{~m})$ for $10 \mathrm{~min}$ to determine pre-disturbance behaviour, categorized as foraging, swimming (i.e. transit between areas) and social behaviour/ resting such as sleeping or preening.

The following experimental disturbance phase consisted of the boat approaching on a straight course towards the flock with a speed of $11.1 \mathrm{~km} / \mathrm{h}$ (6 knots). One observer on board continuously recorded the changes of behavioural responses and flock-to-boat distances. Behavioural responses were categorized as: undisturbed behaviour/no response; alert behaviour (raising their head) — attention towards boat and flocking of individuals; swimming away from the boat; escape diving; sprinting away from the boat with flapping wings or flying away (i.e., the few ducks that had not shed their wing feathers yet).

In the post-disturbance phase, the boat stayed as far as possible away from the flock to not influence their behaviour. The distance between the boat and the flock depended on visibility due to weather and/or island topography (visibility range of on average $585 \pm 216 \mathrm{~m}$; range $150-1000 \mathrm{~m}$ ). The behaviour of the ducks was recorded and the timespan from the end of the disturbance phase until the flock regained predisturbance behaviour was recorded.

Throughout the entire experiment (i.e. from pre-disturbance to post-disturbance) the position of the boat (latitude and longitude based on GPS), the bearing to the flock and the flock-to boat distance and flock positions were recorded. Flock-to-boat distance and flock positions were determined based on GPS-positions in combination with natural landmarks (islands, shallows) and the observers' judgement (approximate accuracy $50 \mathrm{~m}$ ). The water depths at the flocks' positions were afterwards determined from navigational charts. For pre- and post-disturbance positions of the flocks, we assessed the proportion of accessible foraging habitat, using ArcGIS v. 10.1 (ESRI 2013). Water depth has been shown to be the key indicator for suitable foraging habitat in common eiders (Guillemette et al. 1993; Bustnes and Lønne 1997), although other factors such as size of blue mussels Mytilus edulis, which is the main food source of common eiders, may further shape habitat quality (Varennes et al. 2015). Common eiders typically perform dives to less than 6 m of depth (Guillemette 1998; Larsen and Guillemette 2000; Guillemette et al. 2004) and appear to avoid foraging in waters deeper than $20 \mathrm{~m}$ (Bustnes and Lønne 1997). We 
therefore used $20 \mathrm{~m}$ [measured at lowest astronomical tide (Kartverket 2013)] as a threshold to define proportion of accessible foraging habitat within a radius of $150 \mathrm{~m}$ around the flocks' position since common eider flocks typically spread out spatially while foraging. Thus, if the entire benthic area within the $150 \mathrm{~m}$ radius around the flocks' position was $\leq 20 \mathrm{~m}$ deep, the accessible foraging habitat was set to $100 \%$, if it was all deeper than $20 \mathrm{~m}$, it was $0 \%$.

Time was included as hour of the day (range from 8 to $18 \mathrm{~h}$ ). Tidal information was obtained from the Norwegian Mapping Authority (www.kartverket.no) and was categorized into four levels of 2-h duration each: Level 1 represented $1 \mathrm{~h}$ before to $1 \mathrm{~h}$ after low tide, level $21-3 \mathrm{~h}$ after low tide, level $33-5 \mathrm{~h}$ after low tide and level $41 \mathrm{~h}$ before to $1 \mathrm{~h}$ after high tide. Tidal range in the study area and during the study period was on average $1.70 \pm 0.28 \mathrm{~m}$ (range $1.0-2.52 \mathrm{~m}$ ). Wind speed data was downloaded from the Norwegian Meteorological Institute (www.met.no) and was coded according to the Beaufort scale (average 2.78 \pm 1.13 ; range $0-5$ ).

We approached a total of 49 flocks, with an average flock size of $51.8 \pm 49.7$ individuals (range 7-300). The timespan between two separate approaches on flocks in a given area was a minimum of 5 days, and approaches were as such treated as independent events.

\section{Statistics}

The behavioural response of common eiders to the approach distance of a boat was modelled using a series of generalized additive mixed models (GAMMs) in the R package $m g c v$ (Wood 2016) with a logit link function. For each behavioural response (as dependent variable; i.e. undisturbed, alert, swimming, diving, escaping with flapping wings and flying), a binomial GAMM with flock-to-boat-distance as explanatory variable and flock ID as random effect was fitted. GAMMs allow the fitting of non-linear responses to predictor variables, which is a major advantage, as animals rarely respond linearly to their environment (Aarts et al. 2008; Barbraud et al. 2011). To allow a non-linear relationship, we fitted flock-to-boat distance as a smooth-term with a cubic spline smoother. The number of knots, which determine the "wiggliness" of the smoothing, was initially set to a maximum of 4 to avoid overfitting, and we used the functions gam.check and compareML (R package itsadug; van Rij et al. 2017) to check whether models with more knots had a better fit, which was not the case. We subsequently extracted the predicted values and standard errors for each of the six GAMMs. Sample sizes for GAMMs were $N=48$, since flock-to-boat distance was missing in one case.

To assess which variables affected displacement distances, i.e. the distance that a flock escaped from its original position, a set of candidate linear models was fitted and evaluated using information theoretic approaches (Akaike Information Criterion for small sample sizes; AICc; Burnham and Anderson 2002). The variables considered were wind speed, pre-disturbance habitat, flock size, time of day and tidal category. Each of these five variables was included separately in a univariate model at first. Time of day and flock size were included as log-transformed data since original data were not normally distributed and violated model assumptions. From a biological point of view, the effects of pre-disturbance habitat and flock size were of particular interest so we also constructed additive models which included either pre-disturbance habitat or flock size in either addition or in interaction with a second variable (being wind speed, tide, flock size or time of day), and finally one set of models which included pre-disturbance habitat, flock size and one additional variable (being wind speed, tide or time of day). This led to a combination of 23 models, including the null model (see Supplementary material). For the five best models, we in addition to AICc values also present AICc weights $\left(w_{i}\right)$ and adjusted $R^{2}$ values as an indicator of variance explained by the model. We present parameter estimates calculated from model averaging (based on AICc) of all models within $\Delta \mathrm{AICc}<6$, following the suggestions in Symonds and Moussalli (2011), using the R package MuMIn (Barton 2018).

Time until birds returned to pre-disturbance behaviour was analysed using Cox proportional hazard models in the R package survival (Therneau 2015). Since the focus of the study was on the foraging behaviour and influence of the pre-disturbance habitat, only flocks that showed social behaviour/resting or foraging behaviour, but not those that were swimming between areas were included $(N=44)$. Since swimming flocks were changing their habitat, an inclusion into the analysis did not seem meaningful. Two additional flocks were omitted due to missing values, and five flocks did not regain pre-disturbance behaviour but kept swimming (i.e. transit behaviour) and were included in our analyses as right-censored [meaning the model accounted for the fact that the event under study (here: pre-disturbance-behaviour) was not experienced by the last observation]. Models were based on time until flocks returned to pre-disturbance behaviour as the response variable. For the explanatory variables, we adopted the same variables and model structure as previously used for linear models (see above), but additionally added two more variables, namely displacement distance and post-disturbance habitat, resulting in a total of 35 models including the null model (see Supplementary material). As for the linear models, model selection was based on AICc, we present AICc weights and $R^{2}$-values, and parameter estimates were based on model averaging of all models within $\Delta$ AICc $<6$.

In addition to the above-detailed main analyses, we assessed flight initiation distances of moulting 
common eiders, i.e. we identified the mean flock-to-boat distance \pm standard deviation at which birds initiated an energy-demanding escape response, namely diving, escaping with flapping wings or flying. In agreement with other studies investigating flight initiation distances in sea ducks (Schwemmer et al. 2011; Fliessbach et al. 2019), we did not consider swimming here, since this is less energetically demanding behaviour (Norberg 1996).

Finally, we compared whether common eider flocks encountered equally accessible foraging habitat pre- and post-disturbance using a generalized linear mixed model (GLMM) with a binomial distribution in the R package lme4 (Bates et al. 2011). Foraging habitat was fitted as dependent variable, point in time (pre/post-disturbance) as factor and flock ID as random effect.
All statistical procedures were run in $\mathrm{R}$ (version 3.5.1; $\mathrm{R}$ Core Team 2018). Model assumptions were validated using the protocols described in Zuur et al. (2009). Significance level was $p=0.05$. If not stated otherwise, mean values are presented with standard deviation.

\section{Results}

When the boat approached, birds at first showed signs of alertness, which was typically followed by flocks starting to swim away from the boat, a response that was triggered at a maximum flock-to-boat distance of $700 \mathrm{~m}$ (Table 1; Fig. 2). Finally, when the boat approached to a maximum of $400 \mathrm{~m}$, ducks initiated to dive (Table 1, Fig. 2). A small proportion

Table 1 Behaviour of common eider flocks $(N=48)$ in response to an approaching boat

\begin{tabular}{lccc}
\hline Behavioural response & $\begin{array}{l}\text { Most frequent behaviour at a flock-to-boat } \\
\text { distance (m) (output from GAMMs) }\end{array}$ & $\begin{array}{l}\text { Minimum flock-to-boat distance } \\
(\mathrm{m}) \text { (observ. data) }\end{array}$ & $\begin{array}{l}\text { Maximum flock-to-boat } \\
\text { distance (m) (observ. data) }\end{array}$ \\
\hline Undisturbed & 1500 & 150 & 1500 \\
Alert & 330 & 150 & 600 \\
Swimming & 175 & 30 & 700 \\
Diving & 0 & 5 & 400 \\
Flapping & 0 & 40 & 300 \\
Flying & 0 & 30 & 400
\end{tabular}

Behavioural response at minimum and maximum distances to the boat (right side of table) is from observational data. Distances at which each behaviour was most frequently observed (left side of table) are based on the outcome of generalised additive mixed models (GAMMs) and reflect the peak of each behavioural response shown in Fig. 2

Fig. 2 Behavioural response of moulting common eider flocks $(N=48)$ to an experimental approach with a boat. Results are based on binomial generalised additive mixed models (GAMMs) run separately for each behaviour in response to flock-to-boat distance

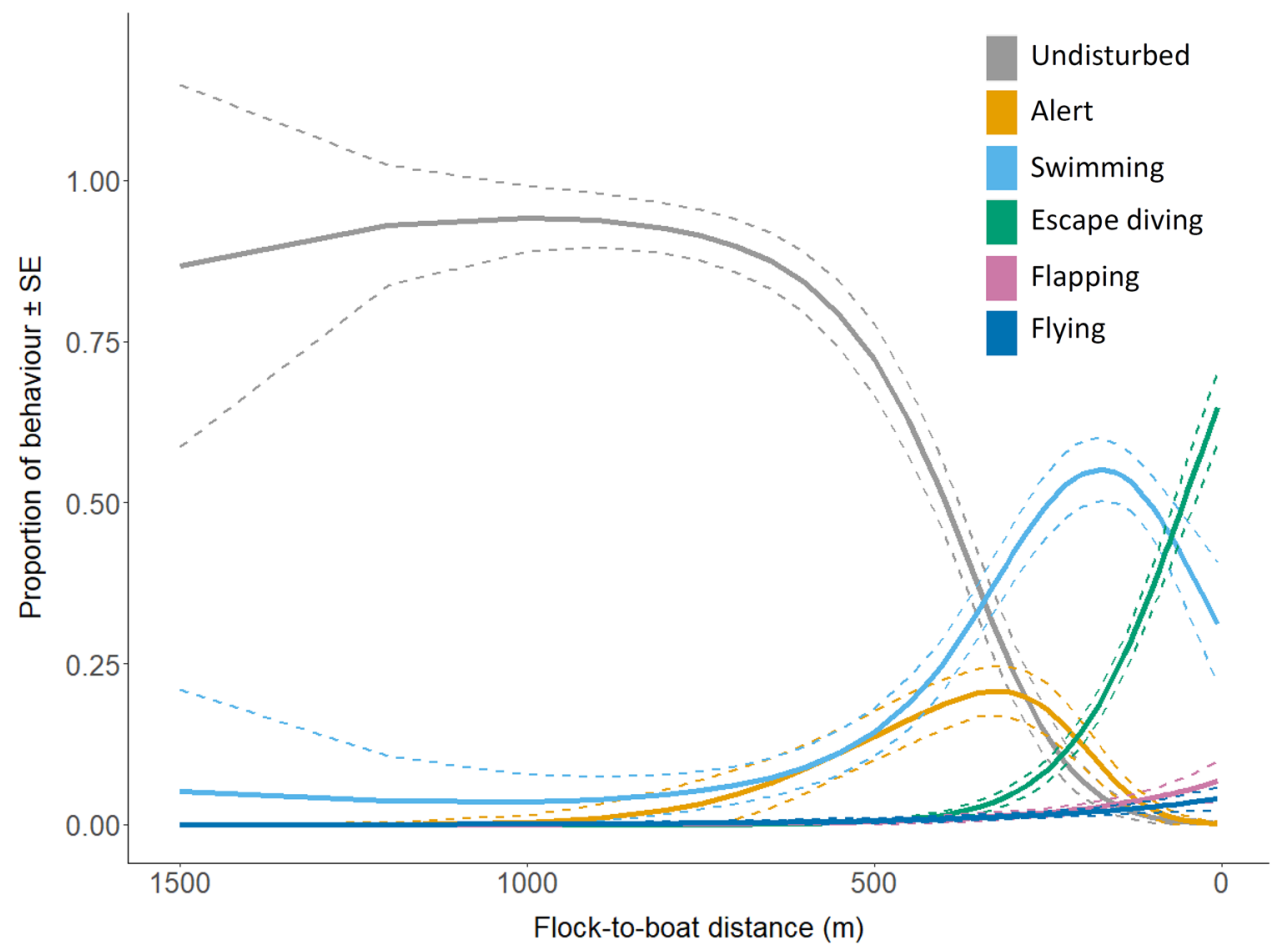




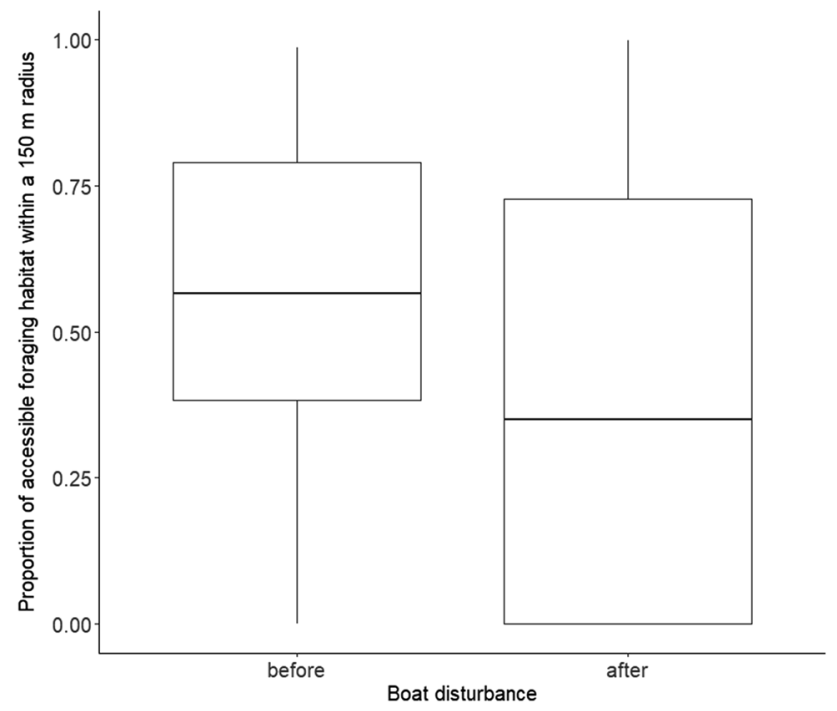

Fig. 3 Box-plot showing the difference in accessible foraging habitat (defined as proportion of benthic area of less than $20 \mathrm{~m}$ depth within a $150 \mathrm{~m}$ radius of the geographical position of each eider flock) before and after boat disturbance. $N=49$

of individuals moved away by flapping or flying (Fig. 2). At a minimum flock-to-boat distance of $150 \mathrm{~m}$, all individuals in all flocks showed disturbance behaviour (Table 1). Based on the observation data, the average flight initiation distances, i.e., the distance at which birds showed an energydemanding evasive response and thus either diving, flapping or flying, were $177 \pm 98 \mathrm{~m}$ (range 30-400 m).
Displacement distance was on average $771 \pm 295 \mathrm{~m}$ (range 283-1462 m). Flocks encountered less accessible habitat at their post-disturbance position compared to their pre-disturbance position (GLMM: $F=4.86, d f=1, p=0.028$; Fig. 3). Displacement distance was best explained by wind speed as single environmental predictor (see Table 2), but overall wind speed explained a comparatively small proportion of variance (adjusted $R^{2}=0.086$ ). Tide and time of day were not supported as explanatory variables in models and their inclusion resulted in higher AICc-values than the null model (Supplementary material). Model averaging over the four most-supported models indicated that displacement distances were shorter under high wind speeds, if pre-disturbance habitat accessibility was high and if larger flocks were disturbed (Table 3).

After disturbance, five flocks which were resting or feeding pre-disturbance, did not return to their pre-disturbance behaviour within the observation period (18-60 min past disturbance) but kept swimming and were thus treated as right-censored in our analyses. The reminder of flocks settled faster, and $75 \%$ of flocks had returned to pre-disturbance behaviour $10 \mathrm{~min}$ after disturbance (Fig. 4). Time-toreturn to pre-disturbance behaviour was best explained by the combination of pre-disturbance habitat and wind speed (Table 4). Based on model averaging, the time-to-return to pre-disturbance behaviour was reduced under higher wind speeds and if pre-disturbance habitat accessibility was high but increased with larger flock sizes and time of day (Table 3).
Table 2 Displacement distance of common eider flocks $(N=49)$ in response to wind speed, flock size, pre-disturbance habitat and time of day

\begin{tabular}{lllllll}
\hline Rank & Model parameters & $K$ & AICc & $\Delta$ AICc & $w_{i}$ & $R^{2}$ \\
\hline 1 & Wind speed & 3 & 697.53 & 0 & 0.24 & 0.086 \\
2 & Pre-disturbance habitat + wind speed & 4 & 698.27 & 0.74 & 0.16 & 0.097 \\
3 & Flock size + wind speed $^{\mathrm{a}}+$ wind speed & 5 & 700.70 & 3.16 & 0.05 & 0.078 \\
4 & Pre-disturbance habitat $\times$ wind & 2 & 700.70 & 3.17 & 0.05 & 0 \\
5 & Null & 2 & 699.64 & 2.10 & 0.08 & 0.032 \\
\hline
\end{tabular}

Only the model characteristics for the best five models (including the null model) are shown. Models with interaction terms (indicated by $\times$ ) included both the main effects and the interaction terms

${ }^{\text {a } L o g-t r a n s f o r m e d ~ d a t a ~}$

Table 3 Parameter estimates for displacement distance (top), and time-to-return to pre-disturbance behaviour (bottom) for those variables included in top models as shown in Tables 2 and 4, based on model averaging (see "Methods")

\begin{tabular}{lcccccc}
\hline & Pre-disturbance habitat & Wind speed & $\begin{array}{l}\text { Pre-disturbance } \\
\text { habitat } \times \text { wind } \\
\text { speed }\end{array}$ & Flock size & Time of day & Flock size $\times$ time of day \\
\hline $\begin{array}{c}\text { Displacement dis- } \\
\text { tance-linear model }\end{array}$ & $-75.80 \pm 174.26$ & $-84.57 \pm 43.26$ & $2.76 \pm 40.47$ & $-3.96 \pm 21.77$ & Not included & Not included \\
$\begin{array}{l}\text { Time to regain pre- } \\
\text { disturbance behav- }\end{array}$ & $2.99 \pm 3.20$ & $0.75 \pm 0.73$ & $-1.07 \pm 1.12$ & $-0.92 \pm 2.50$ & $-1.23 \pm 3.77$ & $0.29 \pm 0.94$ \\
iour-Cox model & & & & & \\
\hline
\end{tabular}




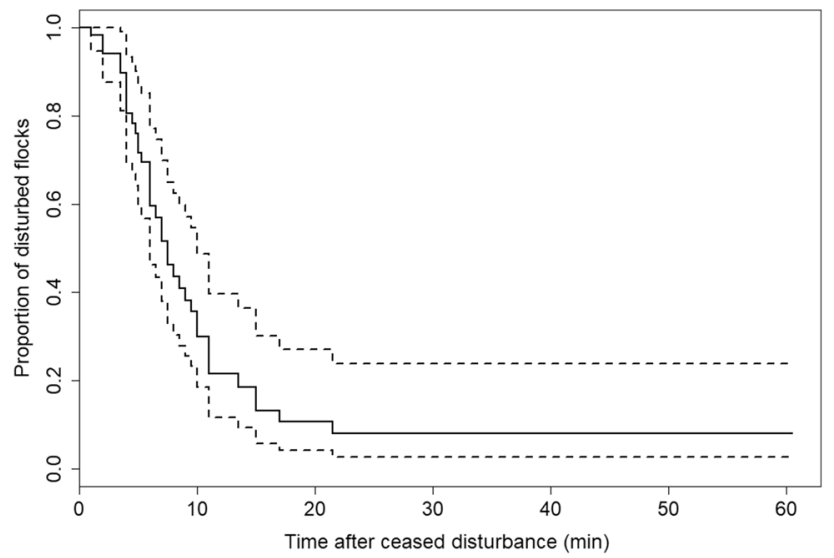

Fig. 4 Visualisation of the best model (see Table 3) to explain timeto-return to pre-disturbance behaviour by common eider flocks. The solid line presents the model estimate, dashed lines present the $95 \%$ confidence intervals. $N=42$ flocks, $N=37$ events ( 5 right-censored)

\section{Discussion}

Our study is the first to investigate the behavioural responses of moulting eider ducks to approaching small boats, a highly relevant topic given the increase in recreational boat traffic in recent years and the overlap in eider duck distribution and moult period with the boating season and coastal area use. We found that moulting common eiders showed flight initiation distances of on average $177 \mathrm{~m}$ and that boat disturbance displaced common eider flocks on average by $771 \mathrm{~m} .75 \%$ of flocks returned to pre-disturbance behaviour within $10 \mathrm{~min}$ after the disturbance had ceased, while few flocks remained disturbed for $45 \mathrm{~min}$ or longer.

In response to an approaching boat, common eiders showed increasing behavioural responses from undisturbed to alert, swimming away and finally diving away, with few birds escaping with flapping wings or flying. Average flight initiation distances of $177 \mathrm{~m}$ are less than what has been found during winter by Schwemmer et al. (2011; average: $208 \mathrm{~m}$ ) and combined throughout the entire year by Fliessbach et al. (2019; average $277 \pm 218 \mathrm{~m}$ ). Possibly, since moulting common eiders are flightless and energetically more constrained to stay near accessible foraging habitats, they reduce their flight initiation and displacement distances in comparison to the rest of the year. On the other hand, the fact that moulting eiders are flightless and constrained in their escape responses could equally be an argument for the opposite pattern, namely longer flight initiation distances in moulting eiders as a strategy to avoid getting trapped. The studies by Schwemmer et al. (2011) and Fliessbach et al. (2019) were conducted with larger ships and at a higher approach speed $(18 \mathrm{~km} / \mathrm{h}$ and $18.5 \mathrm{~km} / \mathrm{h}$, respectively, compared to $11.1 \mathrm{~km} / \mathrm{h}$ in our study), which may have also affected flight initiation distances. Finally, it is possible that-given our study area is popular for recreational boating in summer-eider ducks were already somewhat habituated to boat traffic compared to the offshore areas and the season where/under which the studies by Fliessbach et al. (2019) and Schwemmer et al. (2011) took place, and this again affected flight initiation distances.

Displacement distances in general have been largely neglected in animal escape studies (Cooper Jr. and Blumstein 2015). A recent study in passerines found a positive correlation between flight initiation distances and displacement distances for heavier species, but not for lighter ones (Tätte et al. 2018). It remains open whether this pattern holds true also for other groups of birds. Overall, Tätte et al. (2018) concluded that displacement distances represent an independent and informative additional measure besides the commonly measured flight initiation distances. Since data on displacement distances for common eiders or related diving ducks are lacking (Livezey et al. 2016), we could not make any comparisons between our data and the literature. Similarly, time-to-return to foraging has not been investigated in common eiders or any sea ducks in a comparable fashion as in our study. Schwemmer et al. (2011) investigated return
Table 4 Time of eider flocks to return to pre-disturbance behaviour in response to wind speed, flock size, pre-disturbance and postdisturbance habitat, time of day and displacement distance

\begin{tabular}{|c|c|c|c|c|c|c|}
\hline Rank & Model parameters & $K$ & $\mathrm{AICc}$ & $\Delta \mathrm{AICc}$ & $w_{i}$ & $R^{2}$ \\
\hline 1 & Pre-disturbance habitat $\mathrm{x}$ wind speed & 3 & 221.47 & 0 & 0.31 & 0.226 \\
\hline 2 & Flock size $^{\mathrm{a}}$ & 1 & 223.94 & 2.47 & 0.09 & 0.86 \\
\hline 3 & Flock size $^{\mathrm{a}}+$ wind speed & 2 & 224.46 & 2.99 & 0.07 & 0.122 \\
\hline 4 & Flock size $^{\mathrm{a}} \times$ time of day & 3 & 224.53 & 3.06 & 0.07 & 0.168 \\
\hline 5 & Flock size $^{\mathrm{a}}+$ time of day ${ }^{\mathrm{a}}$ & 2 & 225.35 & 3.88 & 0.04 & 0.103 \\
\hline 6 & Null & 0 & 225.6 & 4.14 & 0.04 & 0 \\
\hline
\end{tabular}

Only the model characteristics for the six best models (including the null model) are shown. $N=42$ flocks, $n=37$ events ( 5 right-censored). Models with interaction terms (indicated by $\times$ ) included both the main effects and the interaction terms

${ }^{a}$ Log-transformed data 
of flocks to their original position (after 60 or $90 \mathrm{~min}$ ) and thus exceeded the time period after disturbance we observed flocks. Merkel et al. (2009) studied the feeding activity of common eiders in response to passing boats but did not publish the actual duration during which birds were disturbed.

If pre-disturbance habitat was highly accessible (i.e. shallow), eider duck flocks displaced shorter distances after disturbance but took longer to return to pre-disturbance behaviour. Furthermore, displacement distances were longer under low wind speeds and for smaller flocks, while time-to-return to pre-disturbance behaviour increased with increasing wind speed but decreased with flock size. Finally, eider flocks took longer to return to pre-disturbance behaviour when disturbed later during the day.

Our result that eider flocks which were located in shallow habitats pre-disturbance had shorter displacement distances but took longer to return to pre-disturbance behaviour may best be explained by optimal foraging theory (Ydenberg and Dill 1986). After being displaced from a good foraging site, ducks should ideally return to their previous patch instead of starting to forage at a likely worse site. They may therefore reduce their displacement distances, but remain alert and active (swimming) longer after disturbance. Our data match the results of a study by Laursen et al. (2016) who investigated displacement strategies and regrouping of common eiders in response to hunting in high-quality feeding areas. Common eiders mitigated risks associated with hunting by re-grouping (seeking shelter in larger flocks during autumn or diluting into smaller, less conspicuous flocks during winter) (Laursen et al. 2016). In contrast, displacement to less productive but undisturbed areas further offshore was identified as a suboptimal decision, since common eiders in offshore areas were in lower body conditions than those in coastal, disturbed areas (Laursen et al. 2016).

Wind speed can affect wave height and thus the energy required to swim away from an approaching boat, but also visibility towards the boat-and in combination with wind direction the engine noise perceived by the ducks. All of these points might explain why displacement distances were lower under stronger wind speeds in our study. Similarly, it has been shown that flight initiation distances in waterbirds in general are lower under higher wind speeds (Laursen et al. 2005). Finally, after the disturbance had ceased, birds may remain more alert under higher wind speeds since windgenerated waves make it more difficult to see the predators (or boat). Finally, increased wave action due to wind might hinder resting or foraging behaviour.

Larger flocks may displace a shorter distance upon disturbance since larger flocks offer relatively higher protection to the individual bird (Cresswell and Quinn 2011) than smaller flocks. Thus, birds of a larger flock experience "safe" conditions at a shorter displacement distance, likely because flock alertness will be shared among more individuals
(Beauchamp 2010). This may also explain why larger flocks returned to pre-disturbance behaviour sooner after the experimental disturbance. Our results contrast, however, with the findings of larger flocks of sea ducks (including common eiders) showing longer flight initiation distances (Schwemmer et al. 2011), a pattern also commonly found among other bird species (Laursen et al. 2005). Further, also contradicting our results, Merkel et al. (2009) found that-focusing on foraging activity only-eider ducks in smaller groups approached normal feeding activity faster than birds in larger groups. Possibly, while flock alertness is shared among more individuals in larger flocks (Beauchamp 2010), variation in behavioural responses and shyness will also be greater in larger flocks. Schwemmer et al. (2011) described that the flight response of the most sensitive individuals within a flock triggered the escape of the entire flock. This could explain the results in the studies by Schwemmer et al. (2011), Laursen et al. (2005) and Merkel et al. (2009), but does not match with our results of larger flocks showing shorter displacement distances and returning earlier to foraging.

Finally, common eiders returned to pre-disturbance behaviour sooner if they were disturbed earlier during the day. If undisturbed, common eiders tend to forage particularly during the morning and evening hours, with decreased foraging activity during midday and at night (Minot 1980; Systad and Bustnes 2001; Merkel et al. 2009). Most of our experiments were conducted between 8 am and $2 \mathrm{pm}$. Thus, our results possibly reflect the birds' increased foraging activity driven by the need for nutrient uptake during morning hours and a reduced need for nutrient uptake later during the day.

We did not find an effect of post-disturbance habitat on time-to-return to pre-disturbance behaviour, and similarly there was no effect of tide on either displacement distance or time-to-return to pre-disturbance behaviour. In particular the first result may be explained by the fact that we did not focus directly on foraging activities of the ducks, but also took resting into account as pre- and post-disturbance behaviour. However, due to their low mobility, we expect moulting eider ducks to stay close to their foraging areas also when they are resting, so the ducks' behaviour pre-disturbance may not be the only explanation. Merkel et al. (2009) found a significant impact of tide on foraging activity of common eiders, yet this study was conducted in areas with a tidal range of $4.5 \mathrm{~m}$, which is about 2.5 times the tidal range that we observed. Thus, we may not have found an influence of tide on displacement distance or time-to-return to predisturbance behaviour due to the comparatively low tidal range in our study area.

We did not take wind direction or other factors into account that may affect the ducks' perception of the boats' engine noise. Besides wind direction — in combination with 
wind speed - this would also involve the transmission of noise under water. Due to the physical properties of water, sound travels much faster and further under water than through air (even under tailwinds) (Everest and Pohlmann 2009). Thus, eider ducks might notice the presence of a boat by acoustical cues under water (especially when diving) rather than through the air. As such, the transmission of the boats' noise might in fact be relevant when investigating distances at which eider ducks changed from pre-disturbance behaviour to an alert state and subsequently initiating a flight escape. However, we did not investigate the influence of wind and other variables on the initial behavioural response towards the approaching boat, but on displacement distances and time-to-return to pre-disturbance behaviour. At the time of flight initiation, ducks should have been visually aware of the boat, since birds during alert behaviour also showed attention towards the boat. Furthermore, since natural predators of diving ducks (especially birds of prey such as white-tailed sea eagles (Haliaeetus albicilla), American mink (Neovison vison) and in rarer cases sea mammals; Anderson et al. 2011; Jaatinen et al. 2011) attack without previous acoustical warning, we believe the visual cue of an approaching boat was more important to determine displacement distances than the noise of the boat. For return to pre-disturbance behaviour, the underwater noise of a nearby boat may be more relevant-but at that time, the engines of our boats were switched off and thus produced no noise. Overall, we therefore consider the effect of wind direction or the boats' noise in general to be negligible in the framework of our study.

Another potential weakness of our study approach was that the boat-to-flock distances at which observations took place before the experimental disturbance approach and post disturbance (250-1500 m and 150-1000 m, respectively) overlapped with the maximum flock-to-boat distance at which birds first responded $(700 \mathrm{~m}$; see Fig. 2). While a larger distance between the boat and the flocks would have been desirable during the observation times, this was practically not possible due to the local conditions with many skerries and small islands, which partly hindered sight onto flocks. We are nevertheless convinced that our results are robust. First, during observations prior to and post disturbance, the boat was stationary, which should be perceived differently by the ducks than a boat moving at considerable speed towards them. Second, we used the behaviour of the eider ducks to judge if our initial approach to the distance at which we observed them (250-1500 m) had already caused a disturbance. Of the 49 flocks, only 5 were swimming prior to our experimental disturbance approach-the reminder was showing clearly undisturbed behaviour (sleeping, preening or foraging). The five flocks that were swimming did so in a perpendicular direction to the boat, seemingly transiting between foraging areas and not swimming away from the boat. Third, the five flocks that did not return to pre-disturbance behaviour within the observation times (i.e. rightcensored in the Cox proportional Hazards Analyses), were 600-1000 m (average $840 \pm 150 \mathrm{~m}$ ) away from our boats during post-disturbance observations, and therefore-except in one case-more than the $700 \mathrm{~m}$ limit. We therefore conclude that overall it is very likely that the flock-to-boat distance during pre- and post-disturbance observations did not affect the results of this study.

The proportion of accessible habitat declined from pre- to post-disturbance, i.e. eider ducks were located over deeper water post-disturbance, which likely increased foraging costs or required the flock to move to another site before resuming to forage. This could affect the birds' body condition. Indeed, Laursen et al. (2016) previously showed that common eiders shot in less suitable habitats were in lower body condition than those in coastal areas with a high abundance of their preferred food, blue mussels. Further, while the majority (75\%) of flocks returned to pre-disturbance behaviour within $10 \mathrm{~min}$ after the disturbance had ceased, five flocks did not settle into pre-disturbance behaviour within the observation times which exceeded 45 min for three of the concerned flocks. This indicates a substantial disturbance after approach with a relatively small boat at comparatively low speed. Many recreational boats drive faster than we did in our study (e.g. Bellefleur et al. 2009; Merkel et al. 2009), which may cause much larger disturbance and long-lasting effects, especially in areas with high boat traffic. Merkel et al. (2009) found that feeding activity in common eiders decreased significantly if boats approached to within $1 \mathrm{~km}$, and there was a cumulative effect if this occurred more than 1 time per hour. As a result of high disturbance, common eiders compensated by feeding also during midday, at night and at high tide (Merkel et al. 2009). Among the seabird and sea duck species occurring in the German North and Baltic seas, common eiders were recently scored as intermediate in regards to behavioural sensitivity to ship traffic, yet highly sensitive when considering the effects of ship traffic on the population level, and they consequently scored as relatively vulnerable to disturbance overall (Fliessbach et al. 2019). We emphasize that for moulting common eiders, which already have an increased energy expenditure (Guillemette et al. 2007), the additional costs for displacement due to ship or boat disturbance, possibly in a highly energy demanding way as flapping or flying (Pelletier et al. 2008) add up. Furthermore, the observed carry-over effects of energetic demands and stress from the moult period to the subsequent breeding season (Harms et al. 2015) highlight the possible consequences of disturbance and energy expenditure during moult on individual fitness and possibly population trajectories.

Given our results, the ongoing population decline of eider ducks in Finland, Sweden and Norway (Ekroos et al. 
2012; Anker-Nilssen et al. 2015; Kilpi et al. 2015), and the expected further increase in coastal recreational and commercial boat and ship traffic, we emphasize the need to reduce disturbance for sea ducks, particularly during moult. Our study provides important quantitative knowledge about the effects of approach of boats on moulting common eiders and can be used for policy-makers to define buffer zones around known moulting sites, e.g. when regulating recreational boat traffic. Such buffer zones should ideally include areas used by common eiders for foraging and resting as well as corridors between both. Further, our results may be used as a knowledge base to create more awareness among boat drivers, particularly those in coastal waters and for recreational purposes.

Acknowledgements We would like to thank Emma Bengtsson, Ingrid Moe Dahl, Alison MacLennon and Kenny Taylor for invaluable assistance during the field period, Kjartan Stensønes at Smøla havstuer and the skippers of the boats, Kjartan Stensønes and Odd Marvin Holberg. This study was funded by the Norwegian Environmental Agency.

\section{Compliance with ethical standards}

Conflict of interest We declare that we have no conflict of interest.

Ethical approval All procedures were in accordance with the ethical standards at NINA and NTNU. Since birds were not handled, animal ethical permissions from the Norwegian authorities were not required.

Open Access This article is licensed under a Creative Commons Attribution 4.0 International License, which permits use, sharing, adaptation, distribution and reproduction in any medium or format, as long as you give appropriate credit to the original author(s) and the source, provide a link to the Creative Commons licence, and indicate if changes were made. The images or other third party material in this article are included in the article's Creative Commons licence, unless indicated otherwise in a credit line to the material. If material is not included in the article's Creative Commons licence and your intended use is not permitted by statutory regulation or exceeds the permitted use, you will need to obtain permission directly from the copyright holder. To view a copy of this licence, visit http://creativecommons.org/licenses/by/4.0/.

\section{References}

Aarts G, MacKenzie M, McConnell B, Fedak M, Matthiopoulos J (2008) Estimating space-use and habitat preference from wildlife telemetry data. Ecography 31:140-160. https://doi.org/10.111 1/j.2007.0906-7590.05236.x

Anderson EM, Esler D, Boyd WS, Evenson JR, Nysewander DR, Ward DH, Dickson RD, Uher-Koch BD, VanStratt CS, Hupp JW (2011) Predation rates, timing, and predator composition for Scoters (Melanitta spp.) in marine habitats. Can J Zool 90:42-50. https:// doi.org/10.1139/z11-110

Anker-Nilssen T, Barrett RT, Lorentsen S-H, Strøm H, Bustnes JO, Christensen-Dalsgaard S, Descamps S, Erikstad KE, Fauchald P, Hanssen SA, Lorentzen E, Moe B, Reiertsen TK, Systad GH
(2015) SEAPOP—De ti første årene. SEAPOP Nøkkeldokument 2005-2014. Trondheim/Troms $\varnothing$

Barbraud C, Rivalan P, Inchausti P, Nevoux M, Rolland V, Weimerskirch $\mathrm{H}$ (2011) Contrasted demographic responses facing future climate change in Southern Ocean seabirds. J Anim Ecol 80:89100. https://doi.org/10.1111/j.1365-2656.2010.01752.x

Barton K (2018) MuMIn: Multi-Model Inference. R package version 1.42.1. https://CRAN.R-project.org/package $=$ MuMIn

Bates D, Maechler M, Bolker B (2011) lme4: Linear mixed-effects models using S4 classes. R package version 0999375-42. https:// CRANR-project.org/package $=1 \mathrm{me} 4$

Beauchamp G (2010) A comparative analysis of vigilance in birds. Evol Ecol 24:1267-1276. https://doi.org/10.1007/s10682-010-9358-5

Bellebaum J, Diederichs A, Kube J, Schultz A, Nehls G (2006) Flucht- und Meidedistanzen überwinternder Seetaucher und Meeresenten gegenüber Schiffen auf See. Ornithologischer Rundbrief Mecklenburg-Vorpommern 45:89-90

Bellefleur D, Lee P, Ronconi RA (2009) The impact of recreational boat traffic on marbled murrelets (Brachyramphus marmoratus). J Environ Manag 90:531-538. https://doi.org/10.1016/j.jenvm an.2007.12.002

Burnham KP, Anderson DR (2002) Model selection and multimodel interference. A practical information-theoretic approach. Springer, New York

Bustnes JO, Lønne OJ (1997) Habitat partitioning among sympatric wintering common eiders Somateria mollissima and king eiders Somateria spectabilis. Ibis 139:549-554. https://doi. org/10.1111/j.1474-919X.1997.tb08860.x

Caro T (2005) Antipredator defenses in birds and mammals. University of Chicago Press, Chicago

Cooper WE Jr, Blumstein DT (2015) Escaping from predators: an integrative view of escape decisions. Cambridge University Press, Cambridge

Cresswell W, Quinn JL (2011) Predicting the optimal prey group size from predator hunting behaviour. J Anim Ecol 80:310-319. https://doi.org/10.1111/j.1365-2656.2010.01775.x

Davenport J, Davenport JL (2006) The impact of tourism and personal leisure transport on coastal environments: a review. Estuar Coast Shelf Sci 67:280-292. https://doi.org/10.1016/j. ecss.2005.11.026

Ekroos J, Fox AD, Christensen TK, Petersen IK, Kilpi M, Jonsson JE, Green M, Laursen K, Cervencl A, de Boer P, Nilsson L, Meissner W, Garthe S, Öst M (2012) Declines among breeding Eider Somateria mollissima numbers in the Baltic/Wadden Sea flyway. Ornis Fenn 89:81-90

ESRI (2013) ArcGIS Desktop: release 10. Environmental Systems Research Institute, Redlands

Everest FA, Pohlmann KC (2009) Master handbook of acoustics. McGraw-Hill Companies, New York

Fliessbach KL, Borkenhagen K, Guse N, Markones N, Schwemmer P, Garthe S (2019) A ship traffic disturbance vulnerability index for Northwest European seabirds as a tool for marine spatial planning. Front Mar Sci 6:192. https://doi.org/10.3389/fmars.2019.00192

Fox AD, Hartmann P, Petersen IK (2008) Changes in body mass and organ size during remigial moult in common scoter $\mathrm{Mel}$ anitta nigra. J Avian Biol 39:35-40. https://doi.org/10.111 1/j.0908-8857.2008.04135.x

Frid A, Dill L (2002) Human-caused disturbance stimuli as a form of predation risk. Conserv Ecol 6:11

Gonson C, Pelletier D, Gamp E, Preuss B, Jollit I, Ferraris J (2016) Decadal increase in the number of recreational users is concentrated in no-take marine reserves. Mar Poll Bull 107:144-154. https://doi.org/10.1016/j.marpolbul.2016.04.007

Guillemette M (1998) The effect of time and digestion constraints in common eiders while feeding and diving over blue 
mussel beds. Funct Ecol 12:123-131. https://doi.org/10.104 6/j.1365-2435.1998.00164.x

Guillemette M, Himmelman JH, Barette C, Reed A (1993) Habitat selection by common eiders in winter and its interaction with flock size. Can J Zool 71:1259-1266. https://doi.org/10.1139/z93-172

Guillemette M, Woakes AJ, Henaux V, Grandbois J-M, Butler PJ (2004) The effect of depth on the diving behaviour of common eiders. Can J Zool 82:1818-1826. https://doi.org/10.1139/z04-180

Guillemette M, Pelletier D, Grandbois J-M, Butler PJ (2007) Flightlessness and the energetic cost of wing molt in a large sea duck. Ecology 88:2936-2945. https://doi.org/10.1890/06-1751.1

Harms NJ, Legagneux P, Gilchrist HG, Bêty J, Love OP, Forbes MR, Bortolotti GR, Soos C (2015) Feather corticosterone reveals effect of moulting conditions in the autumn on subsequent reproductive output and survival in an Arctic migratory bird. Proc R Soc B. https://doi.org/10.1098/rspb.2014.2085

Jaatinen K, Öst M, Lehikoinen A (2011) Adult predation risk drives shifts in parental care strategies: a long-term study. J Anim Ecol 80:49-56. https://doi.org/10.1111/j.1365-2656.2010.01757.x

Jacobsen OW, Morten U (1992) Anti-predator behavior of breeding Eurasian wigeon (Anas penelope). J Field Ornithol 63:324-330

Kaiser MJ, Galanidi M, Showler DA, Elliott AJ, Caldow RWG, Rees EIS, Stillman RA, Sutherland WJ (2006) Distribution and behaviour of common scoter Melanitta nigra relative to prey resources and environmental parameters. Ibis 148:110-128. https://doi. org/10.1111/j.1474-919X.2006.00517.x

Kilpi M, Lorentsen SH, Petersen IK, Einarsson A (2015) Trends and drivers of change in diving ducks. TemaNord 2015:516. Nordic Councils of Ministers, Copenhagen

Larsen JK, Guillemette M (2000) Influence of annual variation in food supply on abundance of wintering common eiders Somateria mollissima. Mar Ecol Prog Ser 201:301-309

Laursen K, Kahlert J, Frikke J (2005) Factors affecting escape distances of staging waterbirds. Wildl Biol 11:13-19. https://doi. org/10.2981/0909-6396(2005)11\%5b13:faedos\%5d2.0.co;2

Laursen K, Møller AP, Holm TE (2016) Dynamic group size and displacement as avoidance strategies by eiders in response to hunting. Wildl Res 22:174-181. https://doi.org/10.2981/wlb.00197

Livezey KB, Fernández-Juricic E, Blumstein DT (2016) Database of bird flight initiation distances to assist in estimating effects from human disturbance and delineating buffer areas. J Fish Wildl Manag 7:181-191. https://doi.org/10.3996/082015-jfwm-078

Lusseau D (2005) Residency pattern of bottlenose dolphins Tursiops spp. in Milford Sound, New Zealand, is related to boat traffic. Mar Ecol Prog Ser 295:265-272

Marine Traffic (2013-2019) www.marinetraffic.org/marine-traffic. Accessed 15 Oct 2019

Merkel FR, Mosbech A, Riget F (2009) Common eider Somateria mollissima feeding activity and the influence of human disturbances. Ardea 97:99-107. https://doi.org/10.5253/078.097.0112

Minot EO (1980) Tidal, diurnal and habitat influences on common eider rearing activities. Ornis Scand 11:165-172. https://doi. org/10.2307/3676120

Norberg UM (1996) Energetics of flight. In: Carey C (ed) Avian energetics and nutritional ecology. Springer US, Boston, pp 199-249

Pelletier D, Guillemette M, Grandbois J-M, Butler Patrick J (2008) To fly or not to fly: high flight costs in a large sea duck do not imply an expensive lifestyle. Proc R Soc B 275:2117-2124. https://doi. org/10.1098/rspb.2008.0422

Ronconi RA, St. Clair CC (2002) Management options to reduce boat disturbance on foraging black guillemots (Cepphus grylle) in the Bay of Fundy. Biol Conserv 108:265-271. https://doi. org/10.1016/S0006-3207(02)00126-X

Schwemmer P, Mendel B, Sonntag N, Dierschke V, Garthe S (2011) Effects of ship traffic on seabirds in offshore waters: implications for marine conservation and spatial planning. Ecol Appl 21:18511860. https://doi.org/10.1890/10-0615.1

Stephens DW, Krebs J (1986) Foraging theory. Princeton University Press, Princeton

Symonds MRE, Moussalli A (2011) A brief guide to model selection, multimodel inference and model averaging in behavioural ecology using Akaike's information criterion. Behav Ecol Sociobiol 65:13-21. https://doi.org/10.1007/s00265-010-1037-6

Systad GH, Bustnes JO (2001) Coping with darkness and low temperatures: foraging strategies in Steller's eiders, Polysticta stelleri, wintering at high latitudes. Can J Zool 79:402-406. https://doi. org/10.1139/z00-213

Tätte K, Møller AP, Mänd R (2018) Towards an integrated view of escape decisions in birds: relation between flight initiation distance and distance fled. Anim Behav 136:75-86. https://doi. org/10.1016/j.anbehav.2017.12.008

R Core Team (2018) R: a language and environment for statistical computing $\mathrm{r}$ foundation for statistical computing, Vienna, Austria. http://www.R-projectorg/

Therneau T (2015) A package for Survival Analysis in S. version 2.38. https://CRAN.R-project.org/package=survival

United Nations Conference on Trade and Development-UNCTAD (2018) Review of maritime transport 2018. United Nations, Geneva

van Rij J, Wieland M, Baayen R, van Rijn H (2017) itsadug: interpreting time series and autocorrelated data using GAMMs R package version 23

Varennes E, Hanssen SA, Bonardelli JC, Guillemette M (2015) A large molluscivore bird (Common eider, Somateria mollissima) is able to discriminate quality of blue mussels (Mytilus edulis) based on size and provenance. Can J Zool 93:655-663. https:// doi.org/10.1139/cjz-2015-0046

Velando A, Munilla I (2011) Disturbance to a foraging seabird by seabased tourism: implications for reserve management in marine protected areas. Biol Conserv 144:1167-1174. https://doi. org/10.1016/j.biocon.2011.01.004

Wood S (2016) package “mgcv" R package version 18-17. https://www. cranr-project.org/web/packages/mgcv/

Ydenberg RC, Dill LM (1986) The economics of fleeing from predators. In: Rosenblatt JS, Beer C, Busnel M-C, Slater PJB (eds) Advances in the study of behavior. Academic Press, Cambridge, pp 229-249

Zuur AF, Ieno EN, Walker NJ, Saveliev AA, Smith GM (2009) Mixed effects models and extension in ecology with R. Springer, New York

Žydelis R, Lorentsen S-H, Fox AD, Kuresoo A, Krasnov Y, Goryaev Y, Bustnes JO, Hario M, Nilsson L, Stipniece A (2006) Recent changes in the status of Steller's eider Polysticta stelleri wintering in Europe: a decline or redistribution? Bird Conserv Int 16:217236. https://doi.org/10.1017/S0959270906000360

Publisher's Note Springer Nature remains neutral with regard to jurisdictional claims in published maps and institutional affiliations. 